\begin{tabular}{c} 
Volume and Issues Obtainable at Center for Sustainability Research and Consultancy \\
Sustainable Business and Society in Emerging Economies \\
ISSN: $2708-2172$ (E): $2708-2504$ \\
Volume 2: Issue 2 December 2020 \\
Journal homepage: $\underline{w w w . p u b l i s h i n g . g l o b a l c s r c . o r g / s b s e e}$ \\
\hline
\end{tabular}

\title{
The Driving Force for Entrepreneurial Performance among Small, Informal Businesses
}

\author{
${ }^{1}$ Simbarashe Muparangi, ${ }^{2}$ Forbes Makudza \\ ${ }^{1}$ Business Management Department, Manicaland State University of Applied Sciences, Mutare, \\ Zimbabwe, smuparangi@gmail.com \\ ${ }^{2}$ Business Management Department, Manicaland State University of Applied Sciences, Mutare, \\ Zimbabwe, forbesmakudza@gmail.com
}

ARTICLE DETAILS

\section{History:}

Revised format: November

2020

Available Online: December

2020

Keywords:

Innovation,Performance,

SMEs, Entrepreneurship

.JEL Classification:

M11,M12

\section{ABSTRACT}

The purpose of the study was to assess the impact of innovation on business performance of informal small business traders in Zimbabwe. The Open Theory of Innovation informed the study whilst data for the study was gathered using structured questionnaires where 175 informal small to medium enterprises (SME) offered validated responses. A causal, quantitative approach was assumed and data was analyzed using SPSS 22 software to identify the association, strength and direction of innovation and innovation determinants on SME performance. The results revealed that innovation is determined by product, process, marketing and organisational factors. The study thus found out that product innovation, process innovation and marketing innovation have strong positive association with SME performance ( $\mathrm{P}$ $<0.05)$. However, the study found an insignificant association between organisational innovation and SMEs performance. The study thus concluded that for informal SMEs to enhance their performance and graduate from being small entities to large corporates, they should embrace product innovation, process innovation and marketing innovation.

\section{OPEN ACCESS}

(C) 2020 The authors, under a Creative Commons Attribution-

NonCommercial 4.0

Corresponding author's email address: forbesmakudza@ gmail.com

Recommended citation: Muparangi, S., \& Makudza, F. (2020). Innovation: The Driving Force for Entrepreneurial Performance Among Small, Informal Businesses. Sustainable Business and Society in Emerging Economies, 2 (2), 1-11

\section{Introduction}

This paper investigates the role of innovation on performance of informal traders. It further presents the antecedent factors of innovation in business and assesses their effect on the performance of informal SMEs. The world has witnessed unprecedented growth in the informal sector at varying degrees depending on the level of development of a country. The phenomena cuts across regions and is also prevalent in Zimbabwe. While the informal SMEs in Zimbabwe have managed to provide $90 \%$ of the 
employment, the sector has failed to provide meaningful return to entrepreneurs, and various stakeholders. At a time when $50 \%$ of the population rely on the SMEs, its performance has been a major obstacle in realizing its full potential (Manyati, \& Mutsau, 2020).

The Finscope Survey (2014) discovered that $80 \%$ of informal SMEs were failing to pay living wages due to poor returns on investment. These findings were further supported by the World Bank (2016) where most SMEs were found to be earning less than US\$5000 in sales per month. The situation has been exacerbated by the economy which has also affected established businesses. The World Bank (2016) discovered that most informal SMEs were failing to employ a considerable number of people and such their contribution to the economy remain minimal.

While innovative practices are at the center of any business growth and performance, it remains to be discovered if the adoption of innovative systems can also enhance performance of informal SMEs. Previous researchers have researched on the influence of innovation on formal SMEs and they have not considered informalized ones (Chan, Teoh, Yeow, \& Pan, 2019; Hussein \& Hassan, 2017; Mahmutaj, 2014; Rosli \& Sidek, 2013; Sussanto, 2017). This leaves literature gaps within the body of knowledge which this study aims to bridge.

\section{Literature Review}

\subsection{SMEs}

Sarpong (2012) argues that the definition of small to medium enterprises (SMEs) differs from one country to another. However, Shumba et al. (2014) indicate that SMEs are defined in terms of sales revenue, employees as well as capital base. The definition of SMEs also follows the dictates of development. In the developing world SMEs are firms fewer than two hundred employees (Kanu \& Sesay, 2016). The World Bank (2016) defines SMEs as those organisations with fewer than three hundred employees and $\$ 15$ million assets. However, that definition in Zimbabwe will fit most of established corporates registered on stock exchange.

Ghana recognizes SMEs as firms with less than 10 employees and this actually mean that some SMEs in Zimbabwe qualify as established businesses in Ghana (Sarpong, 2012). In Zimbabwe, SMEs are those firms with 5 to 100 employees, with an annual turnover less than $\$ 240000$ and an asset base in excess of $\$ 100000$ (Shumba et al., 2014).

\subsection{Performance Measurement for Informal SMEs}

Performance measurement is the process of calculating the efficiency and effectiveness of previous results through acquisition, collation, sorting analysis and interpretation of appropriate data (Kanu \& Sesai, 2016). It is difficult to assess the success of most informal small and medium-sized companies objectively because they do not keep detailed records of their operations. According to Sekere (2016), in the absence of objective performance metrics, the organization may calculate success using gross income, revenue and turnover. Sales are the most commonly used measurement indicators found in the literature (Randika, 2016). They help improve liquidity position of an organisation. In addition, they reflect financial performance outcome because they highlight successful achievements of all the business behaviour required to ensure effective outcome (Shumba, Manzini \& Ndlovu, 2014).

The study also considered profit maximization, market share and number of employees over time as the other metric for sales performance. This was guided by previous studies (Kanu \& Sesai, 2016; Randika, 2016; Sekere, 2016). In that regard, Cheng, (2017) indicates that profit maximization can also be used as a performance measurement metric as the present value of the enterprise.

\subsection{Innovation}

Innovation can be defined as the process of coming up with something new (Sussanto, 2017). Sitharam 
and Hoque (2016) define innovation as the act of coming up with a unique product. However, this definition is not complete as it only associates innovation with products yet innovation is also part and parcel of the service industry process. This position was also noted by Godswill (2015) who argued that innovation is a concept that can be applied in diverse areas.

Therefore, innovation can be classified into various forms which are also part of the definition. There are different types of innovation from literature and these differ from one author to another. Hussein \& Hassan (2017) elaborates that innovation can be categorized into 4 types namely product innovation, process innovation, marketing innovation and organizational innovation.

\subsubsection{Determinants of Innovation among SMEs}

Several ideas and research work were worked on to identify the key antecedents of business innovation among entrepreneurs. The search for these antecedents began way back with the Open Theory of Innovation which argues that innovation is determined by internal and external sources (Santoro, Ferraris, Giacosa, \& Giovando, 2018). The theory posits that employees and owners formulate internal determinants of innovation, whilst the market was positioned as the external driver of innovation (Chesbrough, Lettl, \& Ritter, 2018).

Conversely, the S-Curve theory suggest that innovation is determined by the company's ability to address immediate problems in the market (Chan, Teoh, Yeow, \& Pan, 2019). In support of the S-Curve notion, Ntwoku, Negash and Meso (2018) originality is the key antecedent of innovation as me-too or imitator products fail to be appreciated in the market. The Innovation Diffusion theory highlights that innovation largely depends on the types of customers in the market. Presence of more experimental customers (innovators) drive a company's innovative products through as compared to the presence of more passive customers (laggards).

More recent studies around the globe have established that innovation can be largely driven by product innovation, process innovation, marketing innovation, organisational innovation and technological innovation (Godswill et al., 2016; Mahmutaj, 2014; Makanyeza \& Dzvuke, 2014; Rosli \& Sidek, 2013). Mahmutaj (2014) in Kosovo established that SME innovation was largely a function of product improvement with $19.4 \%$ of new products produced innovatively by the SME sector. A related study in Malaysia by Rosli \& Sidek (2013) discovered that process and product innovation have huge impact on SME performance. Godswill et al. (2016) in Nigeria discovered that all forms of innovation (organisation, marketing, process and product innovation) had statistically significant relationships with SME performance. However, the same study concluded that of the four variables, process and organisational innovation influence SME performance significantly. Conversely, Makanyeza \& Dzvuke (2014) in their study in Zimbabwe found out that innovation was a positive predictor of SME performance. The determinants of innovation they considered were organizational innovation, product innovation, process innovation, and marketing innovation. However, marketing and process innovation had no statistical impact on SME's performance.

The current study noticed that although several determinants are penned and analyzed in literature, there seem to be varying convergence on the real antecedents of innovation. It is against that background that the study posits to be guided by the Open Theory of Innovation and contemporary studies in the development of the determinants of innovation. To that end, the following determinants of business innovation were considered in this study: product, process, marketing and organization.

\subsubsection{Product Innovation}

Product innovation is related to the introduction of a new physical product (Hakannson, 2015). However, Chen (2017) argues that product innovation can also take the form of product modification whereby a few features are added or removed from a product thereby making it new. Mahmutaj (2014) notes that the main aim of product innovation is to increase usage on existing customers and also attracting customers. 
The net impact according to Godswill et al (2017) would be increased sales and profitability.

However, Sussanto (2017) refuted the argument that product innovation always results in improved sales and performance arguing that some of the product innovations do not add value or improve the welfare of consumers thus resulting in decreased sales. Sussanto (2017) also noted that Product innovation takes a great deal of resources through research and development activities and in most cases organisations fail to recoup costs from research and development initiatives.

According to Rosli and Sidek (2013) product innovators are prone to imitators and they fail to gain returns on their efforts, However, Chen (2017) noted that returns on innovation largely depends on a company's strategy from the beginning to the end. In this turbulent economic environment, firms are failing to upstage their competitors due to the rising costs as well as poor outdated products (Hakansson, 2015). According to Joe and Montgomery (2003), companies that use and act on innovation are always ahead of their foes in the industry. Hakansson, (2015) notes that competitiveness is gained through low cost of operation, quality of service and these are guaranteed under the concept of product innovation.

Hakansson (2015) notes that product innovation enables firms to raise the bar in terms of quality as well as its processes and this becomes an advantage in terms of breaking international boundaries. However, Garcia and Calantone (2002) cite that it is costly for SMEs to innovate their products and as such it becomes a futile exercise for SMEs operating in a subdued economic environment.

There is a direct relationship between profitability and adoption of product innovation (Stokes, 2011). Different researchers such as Chen (2017), Hussein and Hassan (2017), Sussanto (2017) have also confirmed to the relationship between product innovation and SME performance. Rosli \& Sidek (2013) discovered the relationship between firm performance and product innovation due to increased demand and sales.

The current study therefore posits that process innovation is a key driver of SME performance and the following hypothesis is thus presented:

H1: There is a significant positive relationship between product innovation and SME performance.

\subsubsection{Process Innovation}

Process innovation is a means to an end. It is common in service industries whereby firms design new ways from delivering the service (Rosli \& Sidek, 2013). Sussanto (2017) highlights that process innovation is also common in the product industry where manufacturing comes up with new ways of manufacturing a product. For example, computerization of the manufacturing process can be termed process innovation.

According to Godswill (2015) process innovation results in efficiency which saves costs as well as improve quality of the final product. In such a scenario it is expected that process innovation is one of the factors which improve performance. Rosli and Sidek (2013) indicate that for process innovation to add value, firms must have enough resources especially human capital to operationalize machinery and systems. However, informal SMEs face challenges such as financial exclusion due to their status. As result it may be difficult for them to adopt process innovation for improved performance.

Furthermore, there is need for replacing traditional methods with modern techniques which are part of a broader concept of process innovation. According to Schmidt and Rammer (2007) productivity is now a function of efficient processes and these can be enhanced through the adoption of technology. In most developing nations, informal SMEs are still using outdated machinery which produce low output.

In a volatile economy, it becomes difficult for firms to enhance their operational performances without the adoption of new processes. The adoption of new technology under technological innovation helps firms to 
increase sales and profitability (Hill \& Rothaermel, 2003). This notion was supported by Hakansson (2015) who found out a statistical significance between process innovation and productivity. Conversely, Thompson et al. (2010) concluded that SMEs which have failed to embrace process innovation struggled to remain viable as their performance kept dwindling. According to Thompson et al. (2010) quality emanating from process innovation can significantly impacts on performance.

Therefore, we have reasons to believe that process innovation is a key driver of business performance and thus we present the following hypothesis:

$\mathbf{H}_{2}$ : There is a significant positive relationship between process innovation and SME performance.

\subsubsection{Marketing Innovation}

Chen (2017) argues that even if a company produces unique quality products, the product may fail due to poor marketing strategies Marketing innovation comprises of new marketing strategies which can result in competitive advantage. Hussein and Hassan (2017) indicate that marketing innovation includes new product design, packaging as well as promotional and pricing strategies. In a nut shell marketing innovation is associated with the marketing mix. The overall performance of an SME depends on how its products are perceived by the customers. Sussanto (2017) argues that innovative marketing helps an organization to increase sales performance through enhanced competitive advantage and brand loyalty.

Without marketing innovation, performance and survival remain a pipe dream. SMEs must be innovative in marketing if they are to entertain the hope of performance, survival and productivity (Hussein \& Hassan, 2017). The corporate graveyard is full of SMEs which have failed to adopt technology in marketing. According to Bergek et al. (2008) business performance depends on its ability to meet the needs of its customers. Marketing innovation provides a business with an opportunity to meet and exceed the needs of customers (Hill \& Rothaermel, 2003).

Studies have shown that there is a direct relationship between firm performance and marketing innovation (Bergek et al. 2008; Hussein \& Hassan, 2017; Sussanto, 2017). It is against that background that the following proposition is made:

H3: There is a significant positive association between marketing innovation and SME performance.

\subsubsection{Organizational Innovation}

Organization innovation is associated with introduction of new ways in which a firm is managed. Most common evidence of organisational innovation can be found in human resource management where organisations invest in HR systems so as to improve efficiency (Gnyawali \& Park, 2011). Godswill et al. (2017) highlight that through organisational innovation, an organization can respond quickly to changes in the environment. Godswill et al. (2017) further note that the introduction of new business practices is also part of organisational wide innovation which can be used to improve service delivery.

Mahmutaj (2014) argues that organisational innovation have the ability to reduce administrative costs which in turn improve organisational performance. While acknowledging the importance of organisation innovation, Rosli and Sidek (2013) concluded that most informal SMEs do not have formal organisational structures thus organisational innovation may not be important in as far as their performance is concerned...

According to Stokes (2011) organisational innovation brings a host of opportunities for entrepreneurs which include sales performance, profitability, stability among others. With increased volatility in the business environment, Gnyawali \& Park (2011) encourage the usage of organisational innovation so as to enhance performance. We therefore have good reasons to suggest that if SMEs embrace organisational 
innovation, performance is guaranteed. The following hypothesis is therefore stated:

H4: There is a significant positive relationship between organisational innovation and SME performance.

\subsection{Conceptual Framework}

Performance of informal SMEs is driven by innovation. Innovative aspects which SMEs need to work on have been identified in literature as product, process, marketing and organisational innovation. Figure 1, conceptualizes these variables.

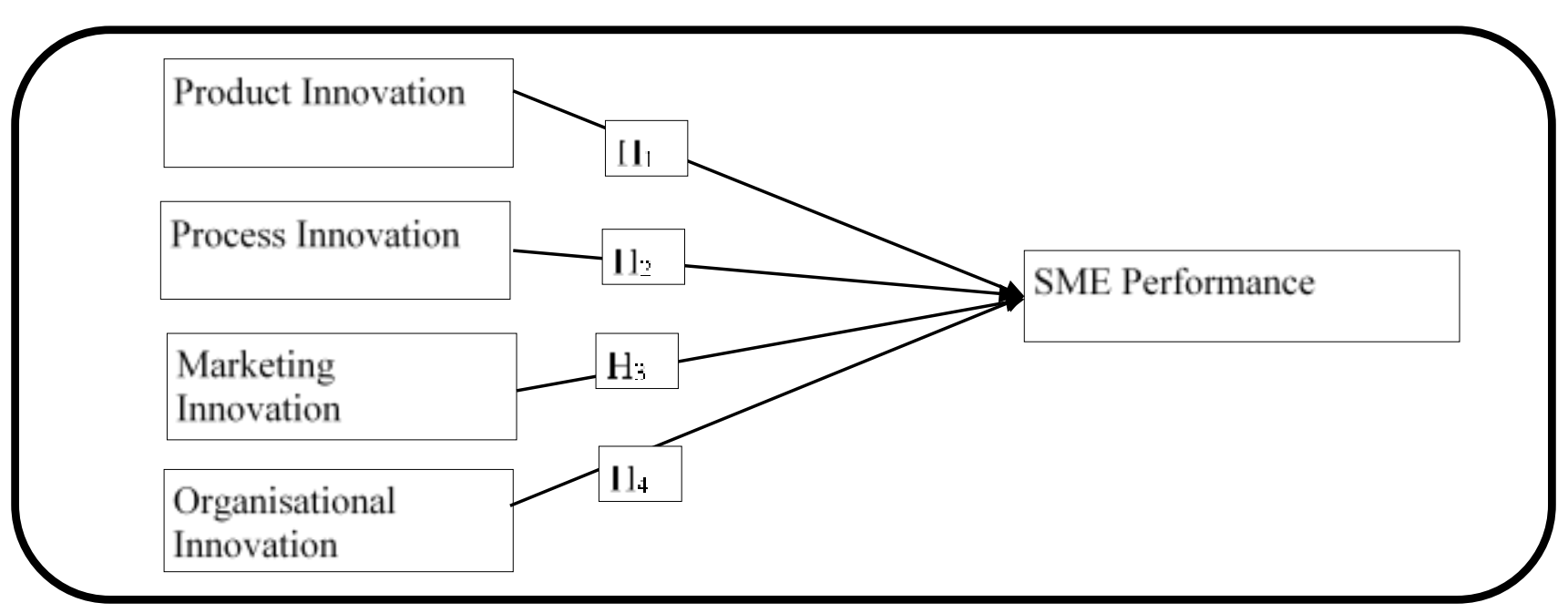

Figure 1: The conceptual framework

We have theorised that SME performance (SMEP) is a function product innovation (ProdI), process innovation (ProcI), marketing innovation (MI) and organisational innovation (OI). Therefore, SME performance is attributed to all four determinants of innovation.

$$
\text { Hence: } S M E P=f n \Sigma[P r o d I+P r o c I+M I+O I]
$$

Thus, the following equation was tested:

$$
\text { SME Performance } \left.=\beta_{0}+\beta_{1} \operatorname{ProdI}+\beta_{2} \operatorname{ProcI}+\beta_{3} M I+\beta_{4} O I+\varepsilon\right)
$$

\section{Research Methodology}

A quantitative survey research method was used in this study. The target population was made up of informal manufacturers operating at Glenview area 8 complex in Harare, Zimbabwe. The number of furniture manufacturers in the complex according to administration data base is 301, which the study used as the numeric value of the target group. The sample size of 200 respondents was then calculated using the rule of thumb where two-thirds of the target population was used. That was supported by Gorejena (2015) who advocated for a high sample size in quantitative studies. Simple random sampling was used to gather data using a structured questionnaire. Researchers maintained high levels of good research ethics throughout the study.

\section{Data Analysis and Results}

\subsection{Data Profiling}

The response rate was $87.5 \%$ which gave rise to 175 validated responses. The reliability of the latent variables was measured using the Cronbach Alpha test and all constructs had coefficients of 0.79 and above. Males dominated the informal SMEs as $70 \%$ of the traders were male respondents while $30 \%$ were females. $40.0 \%$ of the respondents were aged between $40-50$ years while $30.7 \%$ were in the $29-39$ age range. Furthermore $10.7 \%$ of respondents were in the $18-28$ age range, whilst $9.3 \%$ were in the $40-50$ age 
range.

In terms of years of operation, $46.7 \%$ of the SMEs have been operating for the past 1-5 years while $24.0 \%$ of the SMEs have been operating for the past 6-11 years. Further analysis reviewed that $29.23 \%$ of the SMEs have been operating for more than 12 years. With regards to the number of employees, $40 \%$ of informal traders were employing 1-5 people while another $40 \%$ was not employing extra employees. A paltry $4 \%$ was employing more than 23 people. $5.3 \%$ of the traders were employing 6-11 people while $6.7 \%$ was employing $12-17$ people.

In terms of education, $52 \%$ of traders were secondary level education holders, while $21.3 \%$ were holders of certificates. $12 \%$ of the traders had degrees while $8 \%$ had diplomas. $6.75 \%$ of respondents had primary level education as their highest level of education. $40.0 \%$ of the respondents were aged between $40-50$ years while $30.7 \%$ were in the $29-39$ age range. Furthermore $10.7 \%$ of respondents were in the $18-28$ age range, whilst $9.3 \%$ were in the $40-50$ age range

\subsection{SME performance}

Table 1 presents descriptive statistics of the performance of informal SMEs in terms of sales, profits, costs, market share, employment and opening of new businesses.

Table 1: SMEs Performance

\begin{tabular}{llllll}
\hline & N & Min & Max & Mean & Std. Dev \\
\hline Profitability & 175 & 1.00 & 5.00 & 2.13 & 1.63 \\
Sales & 175 & 1.00 & 5.00 & 2.24 & 1.49 \\
Number of employees & 175 & 1.00 & 5.00 & 2.49 & 1.51 \\
Decrease of costs & 175 & 1.00 & 5.00 & 2.04 & 1.44 \\
New shops & 175 & 1.00 & 5.00 & 2.13 & 1.58 \\
Market share & 175 & 1.00 & 5.00 & 2.35 & 1.55 \\
Production & 175 & 1.00 & 5.00 & 2.17 & 1.42 \\
\hline Valid N (listwise) & 175 & & & & \\
\hline
\end{tabular}

Table 1 shows that the highest performance indicator was an increase in the number of employees followed by an increase in the market share. SMEs disagreed that their costs decreased with a mean score of 2.04, whilst they also disagreed that their profits were increasing and that they were opening new outlets.

On average this means that traders disagreed with the assertions that their performance improved in terms of costs, profitability, sales, employees and market share as indicated by mean values of less than 3 and standard deviations of more than 1 . The mean figures are below the average performance standard. The results on performance are in congruent with Gorejena (2015) and World Bank (2016) where SMEs were discovered to be facing serious viability challenges which threatened their survival.

\subsection{The relationship between innovation and informal SME performance}

To analyse the relationship between innovation and SME performance, correlation and regression test statistics were used. The findings are in tables below 2, 3 and 4.

Table 2: Correlation Analysis

\begin{tabular}{llr}
\hline & & SME Performance \\
\hline Product Innovation & Correlation Coefficient & $.885^{* *}$ \\
& Sig. (2-tailed) & .000 \\
Process Innovation & $\mathrm{N}$ & 175 \\
& Correlation Coefficient & $.674^{* *}$ \\
& Sig. (2-tailed) & .000
\end{tabular}




\begin{tabular}{llr} 
& $\mathrm{N}$ & 175 \\
Marketing Innovation & Correlation Coefficient & $.806^{* *}$ \\
& Sig. (2-tailed) & .000 \\
& $\mathrm{~N}$ & 175 \\
Organisational Innovation & Correlation Coefficient & .015 \\
& Sig. (2-tailed) & .068 \\
$\mathrm{~N}$ & 175 \\
\hline **. Correlation is significant at the 0.01 level (2-tailed). & \\
\hline
\end{tabular}

Table 3: Regression Model Summary

\begin{tabular}{l|l|l|l|l}
\hline Model & $\mathrm{R}$ & $\mathrm{R}$ Square & Adjusted R Square & Std. Error of the Estimate \\
\hline 1 & $.641^{\mathrm{a}}$ & .651 & .642 & .38743 \\
\hline a. Predictors: (Constant), Product Innovation, Process Innovation, Marketing Innovation, Organisational Innovation. \\
\hline
\end{tabular}

Table 4: Coefficients

\begin{tabular}{|c|c|c|c|c|c|c|}
\hline \multirow{2}{*}{\multicolumn{2}{|c|}{ Model }} & \multicolumn{2}{|c|}{$\begin{array}{c}\text { Unstandardized } \\
\text { Coefficients }\end{array}$} & Standardized Coefficients & \multirow[t]{2}{*}{$\mathrm{t}$} & \multirow[t]{2}{*}{ Sig. } \\
\hline & & $\mathrm{B}$ & Std. Error & Beta & & \\
\hline \multirow[t]{5}{*}{1} & (Constant) & 1.924 & .053 & & -2.335 & .020 \\
\hline & Product Innovation & .691 & .014 & .678 & 69.831 & .000 \\
\hline & Process Innovation & .621 & .022 & .632 & 66.543 & .000 \\
\hline & Marketing Innovation & .565 & .034 & .625 & 64.322 & .000 \\
\hline & Organisational Innovation & .122 & .021 & .121 & 0.760 & .231 \\
\hline
\end{tabular}

a. Dependent Variable: Informal SME Performance

Table 3 indicates that $65 \%$ of the change in Informal SME performance is explained by product innovation, process innovation, marketing innovation and organisational innovation. Factors which are not part of this study account for the remaining 35\%. Analysis of variance (ANOVA) was used to determine the fitness of the model. The ANOVA results $(\mathrm{F}=7.304, \mathrm{p}=.000)$ indicate that the model is statistically significant.

Using results from Tables 2, the correlation shows that product innovation has a significant, strong positive association with performance of informal SMEs $(r=0.885, p=0.00)$. This means that if SMEs enhances innovation of products, they are more likely to perform better. The regression results show a beta score of $67.8 \%(\mathrm{p}=0.00)$ which indicate a high impact of product innovation on performance. Therefore, the first hypothesis $\left(\mathbf{H}_{1}\right)$ is accepted. Results are in agreement with findings of Chen (2017) and Hussein and Hassan (2017) who discovered that product innovation results in increased performance due to increase in customers. However, the results refute Sussanto (2017)'s assertion that product innovation is a costly endeavour which does not add value to an organisation.

The second hypothesis sought to measure the influence of process innovation on performance of informal SMEs. The results in Table 2 point to a strong positive relationship between process innovation and performance with a correlation coefficient of 0.674 and a $p$-value of 0.00 . This means that the more innovative the SMEs' processes the better their performance. Table 4 results also support a high impact of process innovation on SME performance $(\beta=0.63, \mathrm{P}=0.00)$. Therefore, the second hypothesis $\left(\mathbf{H}_{2}\right)$ is accepted. The results in terms of this hypothesis are in agreement with Godswill et al. (2015) study in Nigeria who states that process innovation reduce operating costs which then translates to improved profitability. The results also coincide with Sussanto (2017) who discovered that process innovation can improve quality of products which results in increased demand and profitability.

The third hypothesis meant to test the association between marketing innovation and SME performance. Tables 2 and 4 show that marketing innovation has a direct relationship with performance $(\mathrm{r}=0.806, \beta=$ $0.625 ; \mathrm{p}=0.00$ ). This means that SMEs need to enhance their marketing innovation so as to improve their 
performance by a factor of $63 \%$. Therefore, the third hypothesis $\left(\mathbf{H}_{3}\right)$ is accepted. The results are in agreement with Hussein and Hassan (2017)'s findings where marketing innovation was chief reason for increased sales within the SME sector. Chen (2017) notes that social media is one of innovative tools available to SMEs at less cost.

The fourth hypothesis assessed the relationship between organisational innovation and SME performance. The study found a correlation coefficient of 0.015 and a beta value of 0.121 with an insignificant $p$-value $(\mathrm{P}>0.05)$. This means that organisational innovation does not influence SME performance directly. Therefore, the fourth hypothesis $\left.\mathbf{( H}_{\mathbf{4}}\right)$ was rejected. The results contradict Godswill et al (2017)'s assertion that organisation innovation results in a more efficient organisation. However, this result was attributed to the fact that informal SMEs operate without proper organisational structures hence organisational innovation is not seen as an important aspect in terms of performance improvement.

\section{Conclusion}

The study concluded that innovation in business is a key driver of informal SMEs performance. If informal traders become more innovative, they are more likely to enhance performance and move from the current status quo which the study found to be stagnant in terms of sales, profitability, market share and employee recruitment.

Guided by literature, the study identified four determinants of innovation in business namely, product, process, marketing and organisational. Findings indicate that SMEs are focusing more on marketing and product innovation mostly. However, the study also concluded that process and organisational innovation were not prioritised. Hypotheses tests done to test the relationships between innovation determinants and SME performance show that product, process and marketing innovation have strong positive correlations with SME performance. However, there was no evidence of statistical association between organisational innovation and SME performance.

Though the study managed to confirm the role of innovation in small entities, it suffered some limitations. The study is limited in terms of generalisation. The findings of this study can only apply to the target group as informal SMEs vary in complexity and dynamics. Furthermore, the study adopted a quantitative study which failed to assess qualitative issues in terms of innovation. Regardless of the said limitations, the study managed to offer meaningful contributions which can enhance performance of informal SMEs. Future studies may want to retest the presented model to enhance the robustness of the model.

\section{References}

Bergek, A., Jacobsson, S., Carlsson, B., Lindmark, S., \& Rickne, A. (2008). Analyzing the functional dynamics of technological innovation systems: A scheme of analysis. Research policy, 37(3), 407429.

Buigut, S. (2015). The Effect of Zimbabwe's Multi-Currency Arrangement on Bilateral Trade: Myth Versus Reality. International Journal of Economics and International, 5(3), 690 - 700.

Chan, C. M., Teoh, S. Y., Yeow, A., \& Pan, G. (2019). Agility in responding to disruptive digital innovation: Case study of an SME. Information Systems Journal, 29(2), 436-455.

Chen, S. (2017). The relationship between innovation and firm performance: A literature review. Advances in Computer Science Research, 82(7), 23-35.

Chesbrough, H., Lettl, C., \& Ritter, T. (2018). Value creation and value capture in open innovation. Journal of Product Innovation Management, 35(6), 930-938.

Finscope. (2012). Zimbabwe - FinScope MSME survey 2012. World Bank

Garcia, R., \& Calantone, R. (2002). A critical look at technological innovation typology and innovativeness terminology: A literature review. Journal of Product Innovation Management: An International Publication of the Product Development \& Management Association, 19(2), 110132. 
Gnyawali, D. R., \& Park, B. J. R. (2011). Co-opetition between giants: Collaboration with competitors for technological innovation. Research Policy, 40(5), 650-663.

Godswill, M., Oyebisi, T., \& Willie, W. (2015). Effects of innovation on performance of manufacturing SMEs in Nigeria: An empirical study. Journal of Small Business and Enterprise Development, 7(2):123-134.

Gorejena, S. (2015). An analysis of the perceived benefits of, and barriers to formalisation among the informal entrepreneurs in Harare metropolitan area. Available at www.ir.uz.ac.zw.(Accessed on 5 February 2020).

Hakansson, H. (2015). Industrial Technological Development (Routledge Revivals): A Network Approach. Routledge.

Hill, C. W., \& Rothaermel, F. T. (2003). The performance of incumbent firms in the face of radical technological innovation. Academy of Management Review, 28(2), 257-274.

Hussein, A., \& Hassan, A. (2017). The impact of innovation on small and medium enterprises performance: Empirical evidence from Hargeisa, Somaliland. International Journal of Academic Research in Business and Social Sciences, 7(8): 22-69.

Joe, T., \& Montgomery, H. F. (2003). Service innovation: Organizational responses to technological opportunities and market imperatives. World Scientific.

Kanu, A. M., \& Sesay, I. (2016). The practice of performance measurement in small and medium enterprises: Empirical evidence from a developed economy perspective. Quarterly Journal of Business Studies, 2(3), 160-173.

Mahmutaj, L. (2014). The impact of innovation in SME's performance. International Scientific Journal (special edition) Economics, 10(12): 115-497.

Makanyeza, C., \& Dzvuke, G. (2015). The influence of innovation on the performance of small and medium enterprises in Zimbabwe. Journal of African Business, 16(1-2), 198-214.

Manyati, T. K., \& Mutsau, M. (2020). Factors that limit the development, prototyping and adoption of informal innovations in Zimbabwe: Lessons for policymakers. African Journal of Science, Technology, Innovation and Development, 1-7.

Ntwoku, H., Negash, S., \& Meso, P. (2017). ICT adoption in Cameroon SME: application of Bass diffusion model. Information Technology for Development, 23(2), 296-317.

Rammer, C., \& Schmiele, A. (2008). Drivers and effects of internationalising innovation by SMEs. $Z E W$ Centre for European Economic Research Discussion Paper, 8 - 35.

Randika, M. (2016). Critical successes factors and performance of the SMEs in Galle division. Word Journal of Studies in Entrepreneurship, 1(1), 13-25

Rosli, M. \& Sidek, S. (2013). The impact of innovation on the performance of small and medium manufacturing enterprises: Evidence from Malaysia. Journal of Innovation Management in Small \& Medium Enterprise, 1-16.

Santoro, G., Ferraris, A., Giacosa, E., \& Giovando, G. (2018). How SMEs engage in open innovation: a survey. Journal of the Knowledge Economy, 9(2), 561-574.

Sarpong, D. (2012). Micro, small and medium scale enterprises in Ghana: Challenges and prospects: A case study of Sekondi-Takoradi Metropolis', Accessed at www.ccsenet.org/journal/index on 27/02/2020.

Schmidt, T., \& Rammer, C. (2007). Non-technological and technological innovation: strange bedfellows? ZEW-Centre for European Economic Research Discussion Paper, (07-052).

Sekere, E. K. (2016). Impact of Mobile Phone Communication on SME Performance: A Case of Selected Units (Doctoral dissertation, United States International University-Africa).

Shumba, V., Manzini, M., \& Ndlovu N. (2014). The journey towards productive entrepreneurship: A theoretical review of the entrepreneurial landscape in Zimbabwe. International Journal of Economic, Commerce and Management, 2(7), 1-13.

Sitharam, S., \& Hoque, M. (2016). Factors affecting the performance of small and medium enterprises in KwaZulu-Natal, South Africa. Problems and Perspectives in Management, 14(2-2), 277-288.

Stokes, D. E. (2011). Pasteur's quadrant: Basic science and technological innovation. Brookings Institution Press. 
Sussanto, A. (2017). Improve performance of SMEs through innovation strategies in developing countries. International Journal of Scientific \& Technology Research, 6(10): 77-86.

Thompson, F. E., Subar, A. F., Loria, C. M., Reedy, J. L., \& Baranowski, T. (2010). Need for technological innovation in dietary assessment. Journal of the Academy of Nutrition and Dietetics, 110(1), 48-51.

Tidd, J., \& Bessant, J. R. (2018). Managing innovation: integrating technological, market and organizational change. John Wiley \& Sons. 